Original Research Paper

\title{
On the Systematic Variation of German Idioms: Converse Pairs as a Constructional Phenomenon
}

\author{
Dmitrij Dobrovol'skij \\ Russian Language Institute, Russian Academy of Sciences, Moscow, Russia
}

Article history

Received: 02-05-2015

Revised: 04-06-2015

Accepted: 05-06-2015

\begin{abstract}
This paper presents some findings of my research on the systematic variation of German idioms, with attention focused on converse transformations such as (jmdm.) eins/eine/einen aufs Dach geben literally "to give someone <let someone have> one on the roof", meaning 'to strike $<$ beat> someone' or 'to punish someone' - eins/eine/einen aufs Dach bekommen (von jmdm.) literally "to get one on the roof from someone", meaning 'to be struck <beaten> by someone' or 'to be punished by someone'. To be subjected to converse transformations an idiom must have two active valencies. These valencies are usually filled by the Agent and Patient, more seldom by the Agent and Addressee or Beneficiary. This semantico-syntactic condition is also a constructional phenomenon because it is governed by the argument structure of a given expression. Within every semantic field, a certain constructional pattern underlies the converse transformation. Cf. for the semantic fields (1) PHYSICAL COERCION, PHYSICAL VIOLENCE and (2) PUNISHMENT, which is derived from (1): [X gab eins in/auf "gave one in/on" \{body part\} of $\mathrm{Y}]$ meaning 'X struck $<$ beat $>\mathrm{Y}$ ' $\leftrightarrow[\mathrm{Y}$ bekam eins in/auf "got one in/on" \{body part\} of Y vom "from" $\mathrm{X}]$ meaning ' $\mathrm{Y}$ was struck $<$ was beaten $>$ by $\mathrm{X}$ '.
\end{abstract}

Keywords: Idiom, Systematic Variation, German, Converse Pair, Constructional Pattern

\section{Introduction}

Recent studies have shown that idioms very typically display variation in their lexical structure. The use of large-scale text corpora has replaced the traditional notion that the lexical structure of idioms is rigidly fixed with a sense that variation in their structure is practically unlimited. The truth, of course, is somewhere in between. Certain idioms permit a wide range of variation, while others tend not to. The question arises as to whether it is possible to predict which idioms undergo which modifications. Yes and no. Variation can be considered more or less regular, first of all, in the field of so called systematic variation. Moon (1998: 139-145) includes in this variation converse, causative, resultative, inchoative, etc. transformations. Cf. German (wieder) auf die Beine kommen - (jmdm.) (wieder) auf die Beine helfen literally "to come (back) on the legs - to help someone (back) on the legs", meaning 'to cure or recover, also financially - to help someone recover, also financially' (cf. English idioms to get back on one's feet and to help someone back on their feet); im Dreck sitzen - (jmdn.) in/durch den Dreck ziehen - (jmdn.) aus dem Dreck ziehen literally "to sit in the mud - to pull someone in/through the mud - to pull someone out of the mud", meaning "to be in a difficult situation - to force someone into a difficult situation - to help someone out of a difficult situation'.

\section{Materials and Methods}

The present study based on extensive corpus data will present research findings on these properties, with attention focused on converse transformations of German idioms. My data is drawn from the text corpus DeReKo (Deutsches Referenzkorpus) of the German Language Institute in Mannheim.

The first step of analysis was aimed at the selection of idioms that are widely used in present-day German. The initial basis of my idiom list was provided by Dobrovol'skij's (1997b) Nemecko-russkij slovar' živyx idiom "German-Russian Dictionary of Current Idioms" 
which contains about 1000 items in all. While working on the monograph (Dobrovol'skij, 1997a), I conducted a detailed survey in which informants were asked to take into account not only the units that they felt were widely used in contemporary speech, but also those that were judged to be generally known although not necessarily used. In other words, a distinction was drawn between passive and active command of the phraseology. Combining these two idiom lists resulted in a new, expanded list that was supplemented in the course of working with the corpora. At present my idiom list contains some 2000 idioms with variants. There is reason to believe that it covers a majority of commonly used and most familiar idioms of the contemporary German literary language.

In the second step of analysis I selected all idioms that form converse pairs such as grünes Licht geben grünes Licht bekommen "to give [a/the] green light - to get [a/the] green light", meaning 'to give permission - to get permission'. All these idioms were searched in the German text corpus DeReKo. The analysis of corpus examples allowed for discovering factors that contribute to systematic variation of this kind.

\section{Theoretical Framework}

The conversive of an expression A is any expression $\mathrm{B}$ that denotes the same situation but differs with respect to diathesis (Diathesis is understood in the sense of Mel'čuk and Xolodovič (1970: 117) as the correspondence between the semantic and syntactic roles of a predicative expression). Cf. eins/eine/einen aufs Dach geben (Der Kanzler hat dem Außenminister eine aufs Dach gegeben "the Chancellor gave the foreign Minister one on the roof', 'the Chancellor criticized the foreign Minister') - eins/eine/einen aufs Dach bekommen (Der Außenminister hat vom Kanzler eine aufs Dach bekommen "the foreign Minister got one on the roof from the Chancellor", 'the foreign Minister was criticized by the Chancellor'). My examination of conversives in phraseology is limited to instances in which the converse transformations are produced through lexical rather than regular grammatical means. Although in theory the formation of passive forms can be considered within the semanticosyntactic category of conversion (cf. Der Kanzler hat dem Außenminister eine aufs Dach gegeben "the Chancellor gave the foreign Minister one on the roof", 'the Chancellor criticized the foreign Minister' vs. Dem Außenminister wurde vom Kanzler eine aufs Dach gegeben "the foreign Minister was given one on the roof by the Chancellor", 'the foreign Minister was criticized by the Chancellor', that is, a sentence which means nearly the same as Der Außenminister hat vom Kanzler eine aufs Dach bekommen "the foreign Minister got one on the roof from the Chancellor", 'the foreign Minister was criticized by the Chancellor'), the passivization of idioms is not treated in this study because it belongs to the sphere of grammar and depends on a number of special conditions. Compare in more detail Dobrovol'skij (2007).

The primary factor contributing to converse transformations is conceptual in nature and goes back to the semantico-syntactic properties of a given idiom. To be subjected to converse transformations an idiom must have two active valencies. These valencies are usually filled by the Agent and Patient, more seldom by the Agent and Addressee or Beneficiary. This semanticosyntactic condition is also a constructional phenomenon because it is governed by the argument structure of a given expression. To meet this argument frame condition, the idiom must represent a certain semantic type, which is why converse idioms are characteristic of some semantic fields and untypical (or even impossible) for others. That is, the primary conversion factor is connected with the semantic class of a given idiom.

In what follows, I shall be examining this type of systematic variation (i.e., converse transformations of idioms) using German data and will show the factors that decisively contribute to regular transformations of the structure and semantics of idioms (cf. a similar analysis based on Russian data in (Dobrovol'skij, 2011a)).

The concept of converse transformations developed within the "Meaning-Text" model and actively employed by the Moscow semantic school (cf. Mel'čuk, 1974; 1988; Apresjan, $1975 ; 1995 ; 1998$ ) is also of interest to the description of phraseology. Naturally, conversion is directly connected with paraphrasal relations and in this sense it is one of the axes of the systematic organization of the lexicon. Because the rules of paraphrasing apply to units on all levels of the language system, converse transformations can be understood very broadly (cf. Boguslavskij, 2008). Structures that can be dealt with under the semantico-syntactic category of conversion include passives and other constructions with a passive semantics (cf. in more detail Apresjan, 1995: 264]), decausatives (at least under the condition that the set of actants is preserve), inchoate-causative pairs, etc. The important point is that conversion is a symmetrical relationship; that is, the set of semantic roles of conversives must remain constant (cf. verbs of the type to buy - to sell). In the sphere of phraseology, converse pairs form idioms such as eins aufs Dach geben - eins aufs Dach bekommen.

Together with the "Meaning-Text" model and the Moscow semantic school, an important source for the theoretical framework used in the present study is Construction Grammar (CxG). The interrelationships of Construction Grammar and the theory of phraseology are discussed in the special literature. Cf. especially (Kay and Fillmore, 1999; Booij, 2002; Feilke, 2007; Fillmore, 2006; Dobrovol'skij, 2011b; Ziem and Lasch 2013). 
According to the classical definition in the wellknown work of Fillmore et al. (1988: 504), constructions are "things that are larger than words, which are like words in that they have to be learned separately as individual whole facts." Obviously, this definition applies to phrasemes of all types; that is, all phraseology, which encompasses lexicalized word groups whose meanings are not equal to the sum of meanings of their components, falls within the subject matter of $\mathrm{CxG}$. This conclusion is also confirmed by A. Goldberg's definition: " $\mathrm{C}$ is a construction iff $_{\mathrm{def}} \mathrm{C}$ is a formmeaning pair $<\mathrm{F} i, \mathrm{~S} i>$ such that some aspect of $\mathrm{F} i$ or some aspect of $\mathrm{S} i$ is not strictly predictable from C's component parts or from other previously established constructions" (Goldberg, 1995: 4).

It would be wrong, however, to think that $\mathrm{CxG}$ and phraseology are one and the same thing. The sphere of interest of $\mathrm{CxG}$ is significantly broader. $\mathrm{CxG}$ is a kind of theoretical paradigm that proposes a new view of language in general and the interrelationship between syntactic and lexical semantics in particular. Between Construction Grammar and phraseology there are a number of fundamental differences, primary among which is the fact that $\mathrm{CxG}$ is essentially a syntactic theory, whereas phraseology is a lexical theory. The development of $\mathrm{CxG}$ began with the realization that syntactic schemes are often not indifferent toward how they are filled lexically and that for a complete description of syntax one must also take into account irregular phenomena that often recall the fixed word combinations traditionally studied in phraseology.

Clearly, all phrasemes are constructions. The issue for the theory of phraseology, however, is not so much the relationship between the scope of the notions "construction" and "phraseme" as it is the advantages of describing phraseology in terms of $\mathrm{CxG}$ as compared with the traditional approach. Although there is a tendency within Construction Grammar to include into its purview phrasemes of all types, it is hardly advisable to do so. It is simpler and more economical to describe idioms, proverbs, collocations and other phrasemes with a fixed lexical structure as units of the lexicon rather than as syntactic formations of an irregular nature.

The primary benefit for the theory of phraseology is that the so called constructional phrasemes described in (Dobrovol'skij, 2011b) are brought into consideration as one of the most significant classes of phrasemes. This class is related to the formal or lexically open idioms as opposed to substantive or lexically filled idioms according to Fillmore et al. (1988). Lexically filled idioms are "normal" phrasemes: idioms, collocations, proverbs, whose "lexical make-up is (more or less) fully specified". Formal or lexically open idioms, on the other hand, "are syntactic patterns dedicated to semantic and pragmatic purposes not knowable from their form alone"
(Fillmore et al., 1988: 505). Cf. also the class of schematic idioms addressed in (Croft and Cruse, 2004: 248).

We describe constructional phrasemes as syntactically autonomous expressions with a fixed composition in which certain slots have to be filled: with predicate actants $(\mathrm{X}, \mathrm{Y})$ or propositional actants $(\mathrm{P})$. Cf. (Baranov and Dobrovol'skij, 2013: 88).

The question remains of the usefulness of $\mathrm{CxG}$ theory for the description of "normal", i.e. lexically filled idioms, that is, phrasemes such as to kick the bucket. At first glance, lexically filled idioms are uninteresting from the perspective of $\mathrm{CxG}$. It is possible, of course, to state that like lexically open idioms, they are also constructions, but this terminological resolution provides no substantial benefit to phraseology. Such idioms, after all, remain lexical units and they would not seem to be affected by any advances in the study of phenomena on the boundary between grammar and lexis. There is, however, a significant group of idioms to which we can apply Charles Fillmore's notion of "coining" (Fillmore, 2006: 4): "We can distinguish two kinds of 'creativity" in language. In one case there is the ability of speakers, using existing resources in the language, to produce and understand novel expressions. In the other case, the one for which we use the term coining, a speaker uses existing patterns in the language for creating new resources. [...] Since the ability to create new words, using non-productive processes, is clearly a linguistic ability, it is our opinion that a grammar of a language needs to identify constructions that exist for 'coining' purposes as well."

The principle of "coining" turns out to be central for $\mathrm{CxG}$, which is particularly interested in this ability of native speakers to create new expressions based not on productive rules but on the analogy of existing linguistic forms, which in turn can be not entirely "rule governed", i.e., do not follow regular models. In the sphere of idiomatic expressions it is especially converse forms that are created through "coining". The formation of converse pairs follows rather regular principles and is not only dictated by the communicative demands and semantics of the corresponding expressions, but is also supported by the schemes underlying them.

\section{Results and Discussion}

The most frequently occurring type of converse idioms in German (the idioms discussed here are listed in the appendix at the end of the present article) consists of pairs of expressions with the verb geben 'to give' bekommen 'to get' and their synonyms; cf. eins/eine/einen auf den Deckel geben literally "to give someone <let someone have> one on the lid", meaning 'to strike <beat> someone' or 'to punish someone' (Wenn ich etwas falsch mache, gibt er mir eins auf den 
Deckel. Aber das bringt mich letztlich wieder weiter. [St. Galler Tagblatt, 18.02.1999]) - eins/eine/einen auf den Deckel bekommen/kriegen literally "to get one on the lid from someone", meaning 'to be struck <beaten> by someone' or 'to be punished by someone' (Warum das so sein könnte, weiß er nicht. Herausfinden würde er es aber trotz allem gerne - auch auf die Gefahr hin, dass er dafür erst einmal einen auf den Deckel kriegt. [Frankfurter Rundschau, 12.11.1998]).

In the majority of cases, idioms that are members of converse pairs are semantically symmetrical; i.e., what differentiates their meanings is the component responsible for the diathetic shift. All 14 idioms analyzed here that form converse pairs are semantically symmetrical. Alternating lexical constituents that correspond to the semantic components responsible for the diathetic shift are in 12 cases (6 pairs) geben "to give" vs. bekommen "to get" and their synonyms and in 2 cases ( 1 pair) stehen "to stand" vs. halten "to hold" (cf. the Appendix).

Converse pairs are rather typical of idioms belonging to the semantic field PHYSICAL COERCION, PHYSICAL VIOLENCE. Cf. (jmdm.) eins/eine/einen auf die Nase geben - eins/eineleinen auf die Nase bekommen (von $j m d m$.) literally "to give someone one on the nose - to get one on the nose from someone", meaning 'to strike $<$ beat $>$ someone - to be struck <beaten $>$ by someone', (jmdm.) eins/eine/einen über die Rübe geben - eins/eine/einen über die Rübe bekommen (von jmdm.) literally "to give someone $<$ let someone have $>$ one on the beet - to get one on the beet from someone", meaning 'to strike $<$ beat $>$ someone - to be struck $<$ beaten $>$ by someone'. Here are some examples from DeReKo.

Boxer Gomez gab Skins eins auf die Nase. [Frankfurter Rundschau, 15.01.1998]

"The boxer Gomez gave Skins one on the nose."

'The boxer Gomez let Skins have one on the nose.'

K. verständigt mit seinem Handy die Polizei und bekommt von einem der Jugendlichen eins auf die Nase. [Frankfurter Rundschau, 05.12.1997]

"K. informed the police on his cell phone and got one on the nose from one of the youths."

'K. informed the police on his cell phone and was punched in the nose by one of the youths.'

Das schließe ich kategorisch aus. Selbst wenn ich ihm eins auf die Rübe geben würde, wäre das nur Spaß. [Hamburger Morgenpost, 31.10.2007]
"That I categorically rule out. Even if I were to give him one on the beet, it would only be in fun."

'That I categorically rule out. Even if I were to punch him, it would only be in fun.'

Wer nicht zahlt, kriegt eins über die Rübe, dass ihm das Hirn rausspritzt. [Die Zeit, 08.08.1986]

"Anybody that doesn't pay gets one on the beet so that his brains will squirt out."

'Anybody that doesn't pay will get his brains knocked out.'

Characteristically, here the Agent valency of all correlates with bekommen (or with the colloquial synonym of this verb kriegen) is syntactically optional and in most contexts remains unfilled. However, semantically it is always a part of the argument frame. In this sense the converse idioms of this field prove for the most part to be not fully symmetrical syntactically. Examples of bekommen - correlates with a syntactically filled valency (von jmdm.) are either for one or another reason not entirely standard. This syntactic asymmetry is encountered in the "source" sense of 'physical coercion" as well as in the derived meanings of 'punishment' or 'superiority'. Compare:

Kräftig eins auf die Nase bekommen haben Politiker für ihre neuesten Innenstadt-Pläne. [Mannheimer Morgen, 08.09.2006]

"Politicians have strongly gotten one on the nose for their latest inner city plans."

'Politicans have really taken a beating for their latest inner city plans.'

„Wer jetzt mit den alten Spielchen fortfährt, wird eine über die Rübe kriegen", warnte das Vorstandsmitglied. [Mannheimer Morgen, 17.11.1995]

" "Anyone who plays the old little games now will get one on the beat," the director warned."

" "Anyone who plays the old little games now will get one on the beat," the director warned.'

Bei ihrem ersten Erstliga-Kampf nach achtjähriger Abstinenz haben sie kräftig eins auf die Nase bekommen. [Frankfurter Rundschau, 30.10.1999]

"At their first major league match after eight years of abstention they strongly got one on the nose."

'At their first major league match after eight years of abstention, they got a good beating.' 
Bekommt Tirol heute eins auf die Rübe, ist uns der UEFA-Cup-Platz kaum noch zu nehmen. [Neue Kronen-Zeitung, 03.05.1997]

"If Tirol gets one on the beet today, we are hardly going to get a UEFA cup place."

'If Tirol is beaten today, we are hardly going to get a UEFA cup place.'

Vielleicht verleiht es manchen Menschen sogar Mut, wenn sie sehen, dass es mir mit all meinem Geld nicht nur gut geht, sondern dass ich ab und zu kräftig eins auf den Deckel bekomme. [Zürcher Tagesanzeiger, 22.04.2000]

"Perhaps it even gives many people courage when they see that for me with all my money things do not go exclusively well but that now and again I also strongly get one on the lid." 'Perhaps it even gives many people courage when they see that for me with all my money things do not go well all the time, but that now and again I also take some real punishment.'

Es ist schon deprimierend, wenn man fast die gesamte Freizeit opfert und dann mitansehen muss, wie man Woche für Woche eine auf den Deckel bekommt. Einem Unentschieden stehen 18 Niederlagen gegenüber. [Neue Kronen-Zeitung, 12.05.1998]

"It is really depressing to sacrifice all your leisure time and then have to watch as week after week you get one on the lid. One draw to 18 losses."

'It is really depressing to sacrifice all your leisure time and then have to watch as week after week you get beaten. One draw to 18 losses.'

Thus in the semantic field PHYSICAL COERCION, PHYSICAL VIOLENCE (as well in the semantic fields connected with the sense of 'physical coercion' or 'physical violence' by means of regular polysemy) we most probably have to do with inexact conversives. If, however, semantic symmetry is present, it is often broken syntactically; that is, the surface realization of diathesis becomes asymmetrical.

Within the semantic field PHYSICAL COERCION, PHYSICAL VIOLENCE there are quite a few converse pairs formed on this pattern and most such idioms belong to a lower stylistic register and slangy discourse; for example, the idioms (jmdm.) eins/eine/einen auf den Deckel geben - eins/eine/einen auf den Deckel bekommen; (jmdm.) eins/eine/einen auf die Nase gebeneins/eine/einen auf die Nase bekommen; (jmdm.) eins/eine/einen über die Rübe geben - eins/eine/einen über die Rübe bekommen; (jmdm.) eins/eine/einen aufs Dach geben - eins/eine/einen aufs Dach bekommen indicate the presence of a rather broad (and also occasional) variance in the selection of the verb (Variation is rather large in noun selection as well. The appearance in youth slang of every new nonstandard designation of persons is accompanied by the creation of corresponding converse idioms. This phenomenon is also connected with the fact that in a certain type of discourse, physical punishment is evidently a central concept) and consequently in the productivity of converse pairs of this type; cf. contexts such as:

Wenn er leichtsinnig wird, muss man Goran $\mathrm{ab}$ und $\mathrm{zu}$ auf den Deckel hauen. [Berliner Morgenpost, 31.07.1998]

"Because he is frivolous, from time to time you have to give Goran one on the lid."

'Because he is frivolous, from time to time you have to slap Goran around.'

Seit dem Fußball-Meistertitel lassen wir uns nicht mehr auf den Deckel hauen. [St. Galler Tagblatt, 07.11.2000]

"Since the football championship we no longer let anyone whack us on the lid."

'Since the football championship we no longer let anyone knock us around.'

Und bei Schlägereien gibt es hin und wieder auch für Polizisten eins auf die Nase. [Mannheimer Morgen, 16.06.2000]

"And in fights there is one on the nose for the police as well now and again."

"And in fights the police as well get hit now and again.'

Wie denkt das Publikum? Es denkt, dass den Paparazzi ab und zu eins auf die Nase gehört. [Neue Kronen-Zeitung, 14.01.1998]

"What do the public think? They think than now and then the Paparazzi should get one on the nose."

'What do the public think? They think that now and then the Paparazzi should get a beating.'

Hauen wir dem Noch-Meister eins über die Rübe, sind wir auf halbem Wege zum Pokal, nicht die Salzburger. [Neue Kronen-Zeitung, 16.03.1996]

"If we give the present champion one on the beet, we are halfway to the cup, not the Salzburgers."

'If we beat the present champion, we are halfway to the cup, not the Salzburgers.' 
Ich hatte Gelegenheit, die Wahlen zum USKongress aus der Nähe zu erleben. Dabei haben Clintons Gegner überraschend ordentlich eine aufs Dach gekriegt. [Salzburger Nachrichten, 14.11.1998]

"I had an opportunity to experience the elections to the US Congress close up. Clinton's opponents surprisingly soundly got one on the roof."

'I had an opportunity to experience the elections to the US Congress close up. Clinton's opponents were surprisingly soundly beaten.'

It can be argued that operating in these semantic fields there is a certain constructional pattern which in a generalized form can be represented as $[\mathrm{X}$ gab eins in/auf "gave in/on" \{body part \} of $\mathrm{Y}]$ meaning 'X struck $<$ beat $>\mathrm{Y}$ ' $\leftrightarrow$ [Y bekam in/auf "got in/on" \{body part\} of $\mathrm{Y}$ vom "from" $\mathrm{X}]$ meaning ' $\mathrm{Y}$ was struck $<$ was beaten $>$ by X' (Also included here in the set of "body parts" are metaphorical lexemes such as Dach, Deckel, Rübe and the verbs geben 'to give' and bekommen 'to get' represent corresponding semantic classes. That is, in the structure of specific idioms these concepts can be realized through various linguistic expressions such as hauen, kriegen, es gibt, es gehört and so on). In this regard we can recall the distinction between "coining" and "generating" in Construction Grammar. Whereas "generation" subsumes productive rules that enable speakers to generate and understand novel expressions, by "coining" is meant the creation of various constructions according to a particular pattern that does not possess predictive power ( $\mathrm{Cf}$. also the ideas developed within the Moscow semantic school (by, for example, Apresjan, 2005) on the role of "lexicographic expectations", which, in contrast to productive rules, do not have predictive power).

The formation of converse idioms according to the pattern indicated here clearly falls under the notion of "coining". Any "rules" in this area should be interpreted as such only in the sense that observing them enables conformity to some constructive model developed by the language. The productivity of the corresponding pattern is extremely limited. Nevertheless, the generation of such constructions is systematic rather than chaotic or arbitrary. Thus the idiomatic expressions examined here which have arisen as a result of conversion can be described as constructions created in accordance with a given pattern. This, of course, applies not only to the semantic field PHYSICAL COERCION, PHYSICAL VIOLENCE, but also to the general principles for the formation of converse idioms.

Because many idioms included in the semantic field PHYSICAL COERCION, PHYSICAL VIOLENCE are capable of developing a "non-physical" meaning according to the principle of regular polysemy, they are doubled in these derived meanings in the fields:

- PUNISHMENT, REPROACH, BLAME, ACCUSATION, CRITICISM;

- CONFLICT;

- OPPOSITION, RESISTANCE;

- AGGRESSION.

This ability of theirs to form conversives is, of course, inherited. As often happens with regular polysemy, recently created idioms in the semantic field PHYSICAL COERCION, PHYSICAL VIOLENCE have not yet developed a "non-physical" meaning. Hence, on the one hand, there are idioms that do not derive new, more abstract meanings, so that converse pairs of this type are encountered only within one, so to speak, source semantic field. On the other hand, within the derived semantic classes there occur idiomatic conversives that do not have the source meaning - i.e., in our case, the meaning 'physical coercion' - or this primary sense is quite marginal. For example, the expressions eins/eine/einen aufs Dach geben and eins/eine/einen aufs Dach bekommen belong above all to the fields PUNISHMENT and SUPERIORITY, whereas the sense of 'physical coercion, physical violence' is realized quite rarely.

Thus on the whole, development follows the expected course. On the basis of originally more concrete meanings, over time more abstract meanings arise. For a while both types of meaning co-exist, but subsequently the more abstract meaning can crowd out the concrete one. $\mathrm{Cf}$. analogous observations in the case of the idiom den Geist aufgeben literally "to give up the spirit", meaning originally 'to die', but now almost exclusively used in the secondary meaning 'to stop functioning' in (Dobrovol'skij, 2006).

The image component of the idioms (jmdm.) einen Tritt (in den Hintern) geben "to give a kick (in the butt) to someone" and einen Tritt (in den Hintern) bekommen "to get a kick (in the butt)" goes back to the idea of 'physical coercion' or 'physical violence'. However, in present-day German, these idioms are primarily specific to the semantic fields COMPULSION or PUNISHMENT, REPROACH Or BANISHMENT, EXPULSION, DISMISSAL. The constructional pattern underlying the expressions of these fields is reminiscent of that providing the semantico-syntactic basis for idioms of the fields PHYSICAL COERCION, on the one hand and semantically derived fields such as PUNISHMENT, CONFLICT and OPPOSITION, on the other. However, these constructional patterns are not identical.

Idioms belonging to the semantic fields SUBJECTION, DEPENDENCE vs. COMPULSION, FORCE and CONTROL, SUPERVISION can also form pairs connected by conversion: unter (jmds.) Pantoffel stehen - (jmdn.) unter 
dem Pantoffel halten literally "to stand under someone's house slipper - to hold someone under the house slipper", meaning 'to control someone - to be controlled (mostly by a woman, esp. by his own wife)'. Compare:

Vince ist gerade zu seiner Freundin gezogen, steht aber noch unter dem Pantoffel seiner Mutter. Gelegentlich versucht er aufzumucken, macht jedoch im letzten Moment immer einen Rückzieher. [Frankfurter Rundschau, 06.08.1998]

"Vince has just moved in with his girlfriend, but he still stands under his mother's slipper. Occasionally he tries to rebel, but at the last moment he always backs down."

'Vince has just moved in with his girlfriend, but he is still dominated by his mother. Occasionally he tries to rebel, but at the last moment he always backs down.'

This example shows that the formation of converse pairs in the field of German phraseology is not restricted by the constructional pattern with the verbs geben "to give" and bekommen "to get" and the like.

Yet another semantic field containing idioms connected by conversion is PERMISSION. Cf. expressions such as grünes Licht geben (jmdm. für etw. A) - grünes Licht bekommen (von jmdm. für etw. A) (The valency (von jmdm.) "from someone" in expressions with the verb bekommen "to get" and the valency (für etw. A) "for something" in all expressions of this type are optional. Also the valency (jmdm.) in grünes Licht geben "to someone" is not always realized syntactically) "to give [a/the] green light to someone for something - to get/receive [a/the] green light from someone for something”, as realized in typical contexts:

Das Bauamt hat grünes Licht für einen Anbau ans Museum gegeben. Dort soll das Archiv untergebracht werden. [RheinZeitung, 08.09.2011]

"The Building Department has given [the] green light for an addition to the museum. The archives will be housed there."

'The Building Department has given the green light for an addition to the museum. The archives will be housed there.'

Ben Bernanke (56) kann aufatmen. Er bekommt eine zweite Amtszeit als USNotenbankchef. Der mächtige Bankenausschuss des Senats gab dafür grünes Licht. [Hamburger Morgenpost, 18.12.2009]

"Ben Bernanke can breathe out. He gets a second term as the head of the Federal
Reserve. The powerful Senate Banking Committee gave [the] green light."

'Ben Bernanke can breathe freely. He gets a second term as the head of the Federal Reserve. The powerful Senate Banking Committee gave the green light.'

Warschau. Ein Gericht in Polen gab grünes Licht für die Auslieferung eines mutmaßlichen Agenten des israelischen Geheimdienstes Mossad an Deutschland. [Hamburger Morgenpost, 08.07.2010]

"Warsaw. A court in Poland gave [the] green light for the extradition to Germany of an alleged agent of the Israeli secret service Mossad.“

'Warsaw. A court in Poland gave the green light for the extradition to Germany of an alleged agent of the Israeli secret service Mossad.'

Kind schätzt die Situation als "schwierig, kritisch und hochgefährlich" ein. Aus dem einflussreichen Gesellschafterkreis (der die Gelder für die fünf Nachkäufe in der Winterpause beschaffte) hat Kind für einen sofortigen Trainerwechsel ebenso grünes Licht bekommen wie für die Auflösung des Vertrages mit Sportdirektor Ricardo Moar im Sommer. [Frankfurter Allgemeine, 04.03.2004] "Kind regards the situation as "difficult, critical and highly dangerous." From the influential shareholders (who procured the money for the five buybacks during the winter break) Kind has gotten [the] green light for both an immediate change of coach and the termination in the summer of the contract with sports director Ricardo Moar."

"Kind regards the situation as "difficult, critical and highly dangerous." From the influential shareholders (who procured the money for the five buybacks during the winter break) Kind has gotten the green light for both an immediate change of coach and the termination in the summer of the contract with sports director Ricardo Moar.'

What obviously underlies conversion of this type is an analogy with the non-idiomatic dominant of the synonymous series Erlaubnis geben 'to give permission' - Erlaubnis bekommen 'to get permission'. All idioms of this type are characterized by distinctly expressed analyzability (cf. for this notion Nunberg et al., 1994), where the meaning of the verb in the structure of the idiom is reduced to the lexical function $\mathrm{Oper}_{1}$ and $\mathrm{Oper}_{2}$, respectively (in terms of the "Meaning-Text" theory) and the nominal component is interpreted as 'permission'. In 
terms of the "Meaning-Text" model, converse pairs of the type discussed in this paper are, in general, based on the paraphrase rule [A $\operatorname{Oper}_{12}(\mathrm{X}) \mathrm{B} \leftrightarrow \mathrm{B} \operatorname{Oper}_{21}(\mathrm{X}) \mathrm{A}$ ]. This meaning is "built into" the structure of the traffic metaphor underlying the idioms grünes Licht geben (jmdm. für etw. A) - grünes Licht bekommen (von jmdm. für etw. A), where the green light (as opposed to the red, which symbolizes prohibition) is conventionally assigned the symbolic function of permission.

To conclude our discussion of converse idioms, let us note that forms with the verb bekommen and its synonyms often occur more often than expressions with verbs of the type geben. This holds for idioms such as eins/eine/einen aufs Dach bekommen "to get one on the roof", eins/eine/einen auf die Rübe bekommen "to get one on the beet", meaning 'to be struck <beaten> or punished' in contrast to forms such as eins/eine/einen auf aufs Dach geben "to give someone one on the roof", eins/eine/einen auf die Rübe geben "to give someone one on the beet", meaning "to strike <beat $>$ or punish someone'. However, in the case of grünes Licht geben grünes Licht bekommen "to give [a/the] green light - to get $[\mathrm{a} /$ the] green light", "to give permission - to get permission' and the like, constructions with the verb bekommen and its synonyms occur more seldom. The form unter (jmds.) Pantoffel stehen "to stand under someone's house slipper", 'to control someone' is encountered much more frequently than its converse counterpart (jmdn.) unter dem Pantoffel halten "to hold someone under the house slipper", 'to be controlled'. Consequently, from the viewpoint of usage such converse pairs are mostly asymmetrical. In other words, in the case of converse pairs we have to do not simply with two established idioms between which there is a converse relationship, but with the realization of a systematically determined potential of diathetic variation.

Such asymmetry in the use of the members of converse pairs is evidently due, on the one hand, to the presence of other possible diathetic shifts, - specifically, the possibility of moving the Agent out of focus by elevating the communicative rank of the Beneficiary through, for example, the passivization of a given idiom. On the other hand, such asymmetry is due to differences in communicative salience of the concepts which are members of a semantic opposition, such as DEPENDENCE vs. CONTROL, SUPERVISION.

\section{Conclusion}

On the whole, the data examined here shows that the formation of converse idioms occurs according to certain principles which, however, are not productive rules. Most factors contributing to converse transformations in phraseology are conceptual in nature and go back to semantico-syntactic properties of a given idiom.
From the syntactic point of view, it is decisive that the idiom in question have two active valencies. Semantically, these valencies are usually filled by the Agent and Patient, more seldom by the Agent and Addressee or Beneficiary. Syntactically, the "left" member of the converse pair has a subject valency (corresponding to the Agent) and a valency of the dative object (corresponding to the Patient or Addressee/Beneficiary). Cf. $\mathrm{X}_{\text {sub\&Agent }}$ hat $\mathrm{Y}_{\text {dat_obj\&Patent }}$ eins aufs Dach gegeben " $\mathrm{X}_{\text {sub\&Agent }}$ gave $\mathrm{Y}_{\mathrm{dat} \text { obj\&Patent }}$ one on the roof" or $\mathrm{X}_{\text {sub\&Agent }}$ hat $\mathrm{Y}_{\text {dat_obj\&Beneficiary }}$ grünes Licht gegeben " $\mathrm{X}_{\text {sub\&Agent }}$ gave $\mathrm{Y}_{\text {dat_obj\&Beneficiary [a/the] }}$ green light". The "right" member of the converse pair has a subject valency (corresponding to the Patient or Addressee/Beneficiary) and a valency of the prepositional object with von (corresponding to the Agent). Cf. $\mathrm{Y}_{\text {sub\&Patent }}$ hat (von $\mathrm{X}_{\text {prep obj\&Agent }}$ eins aufs Dach bekommen " $\mathrm{Y}_{\text {sub\&Patent }}$ got (from $\mathrm{X}_{\text {prep_obj\&Agent) one }}$ on the roof" or $\mathrm{Y}_{\text {sub\&Beneficiary }}$ hat (von $\mathrm{X}_{\text {prep obj\&Agent) }}$ grünes Licht bekommen "Y $\mathrm{Y}_{\text {sub\&Beneficiary got (from }}$ $\mathrm{X}_{\text {prep_obj\&Agent }}$ [a/the] green light".

The ability of an idiom to govern these two actants depends on its semantic class, i.e. it must have a meaning that yields a specific argument frame. This ability is grounded both in the semantic type of a given idiom and in the structure of the underlying metaphor. Hence, what is especially important here is the intersection of metaphor and lexicalized meaning. Analysis of my data has shown that converse pairs occur in the structure of a rather narrow circle of semantic fields and that in the field PHYSICAL COERCION, PHYSICAL VIOLENCE and some others that are semantically derived from it, conversion is a fairly typical phenomenon.

As a rule, idioms that are subjected to converse transformations occur in certain constructional patterns, i.e., such idioms display a kind of semantico-syntactic regularity. This is mostly due to the semantic analyzability of the idiom structure. In other words, some constituents or constituent phrases of a given idiom must have a certain semantic autonomy. One part of the idiom (usually the verbal component) is responsible for the transformation and consequently varies (and this variation is regular and predictable in terms of the semantic class), while the other part of the idiom remains unchanged. Thus the members of converse pairs display entirely definite, non-random differences in their lexical structure and these differences on the plane of expression regularly correspond to semantic differences. This alone forces us to perceive all such idioms as analyzable, i.e., consisting of relatively autonomous components. One might think that analyzability does not account for the ability of idioms to participate in converse transformations, but is instead a consequence of the presence in the language of paired idioms connected by the corresponding semantic relations. Such, however, is 
not the case. Supporting the primacy of analyzability is above all the presence of a certain dynamics in the formation of converse correlates. Some of these are interpreted as occasional ones which, although they have not become established in usage, are nevertheless entirely normative expressions. In other words, native speakers intuitively know which idioms permit converse transformations - i.e., possess the systematically determined capability of diathesis variation - and which do not.

Consider the example grünes Licht geben - grünes Licht bekommen "to give [a/the] green light - to get [a/the] green light" discussed above. The nominal group grünes Licht means 'permission' not because there exist two correlating expressions grünes Licht geben and grünes Licht bekommen, but because in the structure of the traffic metaphor a green light is the signal to go ahead. This group is so autonomous semantically that the expressions grünes Licht geben - grünes Licht bekommen can be described as collocations whose structure includes the idiom grünes Licht "green light".

The formation of kindred expressions through analogy is Fillmore's "coining" in a pure form. New expressions are created on the basis of an already developed model, but adherence to this pattern is not a productive rule - that is, the pattern itself does not have predictive power and this is what differentiates "coining" from "generating".

\section{Acknowledgement}

Thanks go to the anonymous reviewers for a number of valuable comments that I have attempted to take into account.

\section{Funding Information}

This paper is based on work supported by the RFFI under Grant 13-06-00403.

\section{References}

Apresjan, J.D., 1975. Leksičeskie konversivy v russkom jazyke [Lexical conversives in Russian]. In: Linguistica Silesiana. Universitet Śląski, Katowice, pp: 71-99.

Apresjan, J.D., 1995. Leksičeskaja semantica [Lexical semantics]. 2nd Edn., Škola jazyki russkoj kul'tury, Moscow.

Apresjan, J.D., 1998. kauzativy ili konversivy? [Causatives or conversives?]. In: Tipologija. Grammatika. Semantika. K 65-letiju V.S. Xrakovskogo [Typology. Grammar. Semantics. Festschrift for V.S. Xrakovskij]. Nauka, Saint Petersburg, pp: 273-281.
Apresjan, J.D., 2005. O Moskovskoj semantičeskoj škole [On Moscow semantic school]. Voprosy jazykoznanija, 1: 3-30.

Baranov, A.N. and D.O. Dobrovol'skij, 2013. Osnovy frazeologii [Foundations of phraseology]. Nauka, Flinta, Moscow.

Boguslavskij, I.M., 2008. Tol'ko li u glagolov est' diatezy? [Do only verbs have diathesis?]. Voprosy jazykoznanija, 6: 6-28.

Booij, G., 2002. Constructional idioms, morphology and the Dutch lexicon. J. Germanic Linguist., 14: 301-329.

Croft, W. and D.A. Cruse, 2004. Cognitive Linguistics. 1st Edn., Cambridge University Press, Cambridge.

DeReKo - Das Deutsche Referenzkorpus des IDS Mannheim im Portal COSMAS II (Corpus Search, Management and Analysis System).

Dobrovol'skij, D., 1997a. Idiome im mentalen Lexikon: Ziele und Methoden der kognitivbasierten Phraseologieforschung. WVT Wissenschaftlicher Verlag Trier, Trier.

Dobrovol'skij, D.O., 1997b. Nemecko-russkij slovar' živyx idiom [German-Russian dictionary of current idioms]. Metatext, Moscow.

Dobrovol'skij, D., 2006. Reguläre Polysemie und verwandte Erscheinungen. In: Von Intentionalität zur Bedeutung konventionalisierter Zeichen. Festschrift für Gisela Harras zum 65. Geburtstag, Proost, K. and E. Winkler (Eds.), Narr, Tübingen, pp: 29-64.

Dobrovol'skij, D.O., 2007. Passivizacija idiom (o semantičeskoj obuslovlennosti sintaksičeskix transformacij vo frazeologii) [Passivization of idioms (on semantic conditions of syntactic transformations in phraseology)]. Voprosy Jazykoznanija, 5: 39-61.

Dobrovol'skij, D.O., 2011a. Konversija i aktantnaja derivacija vo frazeologii [Conversion and actant derivation in phraseology]. In: Slovo i jazyk: Sbornik statej k vos'midesjatiletiju akad, J.D. Apresjana [Word and language: Festschrift for J.D. Apresjan], Jazyki slavjanskix kul'tur, Moscow, pp: 207-227.

Dobrovol'skij, D., 2011b. Phraseologie und Konstruktionsgrammatik. In: Konstruktionsgrammatik III. Aktuelle Fragen und Lösungsansätze, Lasch, A. and A. Ziem (Eds.), Stauffenburg, Tübingen, pp: 111-130.

Feilke, H., 2007. Syntaktische Aspekte der Phraseologie III: Construction Grammar und Verwandte Ansätze. In: Phraseology: An International Handbook of Contemporary Research, Burger, H., D. Dobrovol'skij, P. Kühn and N.R. Norrick (Eds.), de Gruyter, Berlin, New York, pp: 63-76. 
Fillmore, C.J., 2006. Idiomaticity. In: Berkeley Construction Grammar.

Fillmore, C.J., P. Kay and M.C. O’Connor, 1988. Regularity and idiomaticity in grammatical constructions. The case of 'let alone'. Language, 64: 501-538.

Goldberg, A.E., 1995. Constructions: A Construction Grammar Approach to Argument Structure. 1st Edn., The Univ. of Chicago Press, Chicago, London.

Kay, P. and C.J. Fillmore, 1999. Grammatical constructions and linguistic generalizations: The What's X Doing Y? construction. Language, 75: 1-33. DOI: 10.1353/lan.1999.0033

Mel'čuk, I.A., 1974. Opyt lingvističeskix modelej «Smysl $\Leftrightarrow$ Tekst» [Towards the theory of linguistic models "Meaning $\Leftrightarrow$ Text"]. Nauka, Moscow.

Mel'čuk, I.A., 1988. Dependency Syntax: Theory and Practice. 1st Edn., The SUNYPress, Albany, New York.

Mel'čuk, I.A. and A.A. Xolodovič, 1970. K teorii grammatičeskogo zaloga [Towards the theory of grammatical voice]. Narody Azii i Afriki [People of Asia and Africa], 4: 111-124.

Moon, R., 1998. Fixed Expressions and Idioms in English: A Corpus-Based Approach. 1st Edn., Oxford University Press, Oxford, ISBN-10: 019823614X, pp: 338.

Nunberg, G., I.A. Sag and T. Wasow, 1994. Idioms. Language, 70: 491-538. DOI: 10.1353/lan.1994.0007

Ziem, A. and A. Lasch, 2013. Konstruktionsgrammatik: Konzepte und Grundlagen Gebrauchsbasierter Ansätze. 1st Edn., Walter de Gruyter, Berlin, Boston, ISBN-10: 3110295644, pp: 244.

\section{Appendix of Converse Idioms}

(jmdm.) eins/eine/einen aufs Dach geben $\leftrightarrow$ eins/eine/einen aufs Dach bekommen/kriegen (von jmdm.)

(jmdm.) eins/eine/einen auf den Deckel geben $\leftrightarrow$ eins/eine/einen auf den Deckel bekommen/kriegen (von jmdm.)

(jmdm.) grünes Licht geben $\leftrightarrow$ grünes Licht bekommen (von jmdm.)

(jmdm.) eins/eineleinen auf die Nase geben $\leftrightarrow$ eins/eine/einen auf die Nase bekommen/kriegen (von jmdm.)

(jmdm.) eins/eine/einen über die Rübe geben $\leftrightarrow$ eins/eine/einen über die Rübe bekommen/kriegen (von jmdm.)

unter (jmds.) Pantoffel stehen $\leftrightarrow$ (jmdn.) unter dem Pantoffel halten

(jmdm.) einen Tritt (in den Hintern) geben $\leftrightarrow$ einen Tritt (in den Hintern) bekommen/kriegen (von jmdm.) 